\title{
PEMANFAATAN VIDEO PEMBELAJARAN MUATAN PELAJARAN IPS MELALUI PEMBELAJARAN JARAK JAUH MENINGKATKAN HASIL BELAJAR SISWA SD
}

\author{
Marwani \\ SD Negeri Wonosari \\ email: mamaroihanara7@gmail.com
}

\begin{abstract}
ABSTRAK
Penelitian ini bertujuan untuk mengetahui dampak dan hasil pemanfaatan video pembelajaran muatan pelajaran IPS melalui pembelajaran jarak jauh pada siswa kelas VI C SD Negeri Wonosari I, Gunungkidul. Metode penelitian ini adalah deskriptif kualitatatif berdasarkan fakta dan keadaan selama guru melaksanakan pembelajaran jarak jauh. Pada penelitian ini, data-data dikumpulkan melalui observasi, assessment, teknik dokumentasi terhadap datadata yang berkaitan dengan permasalahan motivasi dan hasil belajar siswa selama pembelajaran jarak jauh. Data-data yang dianalisis adalah keadaan awal, pelaksanaan pembelajaran dengan video pembelajaran, hambatan dan strategi pemecahan masalah, dampak serta tindak lanjutnya. Berdasarkan hasil pengamatan dan analisis angket yang diberikan diperoleh bahwa dalam proses pembelajaran tematik terpadu muatan pelajaran IPS dengan video pembelajaran, lebih dari $80 \%$ siswa merasa senang dan tertarik mengikuti pembelajaran. Hal tersebut ditunjukkan pula oleh meningkatnya ketepatan kehadiran siswa di kelas maya dan pengumpulan tugas tepat waktu. Perolehan hasil belajar dapat dideskripsikan bahwa 26 dari 28 siswa mencapai Kriteria Ketuntasan Minimal atau sebesar 92,86\%. Rata-rata nilai yang diperoleh siswa 85,18. Dari indikator tersebut kemudian dijadikan penulis untuk menarik kesimpulan bahwa pemanfaatan video pembelajaran melalui pembelajaran jarak jauh dapat meningkatkan motivasi dan hasil belajar siswa.
\end{abstract}

Kata kunci: video pembelajaran, hasil belajar, pembelajaran jarak jauh

\section{PENDAHULUAN}

Di masa pandemi saat ini, tantangan dan persoalan yang dihadapi di dunia pendidikan menjadi semakin rumit. Kondisi pandemi Covid-19 saat ini telah mengubah sistem dan proses belajar. Dalam kondisi normal, pembelajaran umumnya dilakukan secara langsung tatap muka antara guru dan siswa. Sistem pembelajaran seperti itu membuatnya lebih mudah bagi guru untuk secara langsung mengontrol hasil belajar siswa. Melalui pembelajaran tatap muka juga memudahkan guru untuk memberikan umpan balik dan membantu siswa dalam mengatasi masalah belajar mereka. Dinas Pendidikan, Pemuda, dan Olahraga 
Pemerintah pada tanggal 12 Januari 2021 mengeluarkan Surat Edaran Nomor : 443/00207 tentang pelaksanaan tata kerja Aparatur Sipil Negara (ASN) dan Kegiatan Belajar Mengajar. Dalam surat edaran tersebut disampaikan anjuran pemerintah yang menetapkan pembelajaran di jenjang pendidikan dasar dan menengah dilaksanakan secara daring.

Kompetensi Dasar muatan IPS kelas VI antara lain menganalisis posisi dan peran Indonesia dalam kerjasama di bidang ekonomi, politik, sosial dan budaya, teknologi, dan pendidikan dalam lingkup ASEAN. Cakupan materi yang sangat luas, sehingga menuntut guru harus mampu memilih strategi pembelajaran yang tepat. Metode yang dipilih dan media pembelajaran yang digunakan sangat berpengaruh terhadap keberhasilan pembelajaran. Pemilihan media pembelajaran yang tepat pada masa pandemi Covid-19 merupakan hal penting untuk dipertimbangkan.

Selama pembelajaran jarak jauh muncul berbagai permasalahan yang terjadi. Berdasarkan hasil wawancara dengan beberapa siswa diperoleh informasi bahwa :1) pada pembelajaran jarak jauh beberapa siswa merasa jenuh mengikuti pembelajaran jarak jauh. 2) siswa enggan dengan membaca materi kiriman guru. 3). siswa tidak tertantang untuk mengerjakan tugas dari guru. 4) siswa tidak lagi bersemangat mengerjakan soal evaluasi Apalagi tugas-tugas yang hanya bersifat teoritis dengan cakupan materi IPS yang luas menjadikan siswa enggan bertanya kepada guru atau siswa lain.

Melalui observasi awal tersebut diketahui juga harapan yang disampaikan siswa selama pembelajaran jarak jauh. Siswa memiliki harapan agar proses pembelajaran jarak jauh dilaksanakan lebih menarik sehingga tidak punya alasan untuk tidak hadir di kelas maya. Siswa aktif dalam proses pembelajaran di kelas maya . Siswa dapat mengerjakan tugas tepat waktu dengan senang hati. Siswa bersemangat dalam mengerjakan soal evaluasi.

Peneliti menggunakan video pembelajaran pada saat pembelajaran jarak jauh sehingga dapat melakukan penyesuaian dan meningkatkan kreativitasnya. Video pembelajaran digunakan untuk menyampaikan materi pembelajaran agar lebih mudah dipahami dan dimengerti sesuai dengan minat dan karakteristik peserta didik. Video pembelajaran memberikan kesempatan kepada peserta didik 
untuk mengulang atau menghentikan video supaya lebih memahami materi. Peserta didik juga dapat melewati bagian yang sudah mereka pahami. Oleh karena itu, peserta didik dapat mempercepat proses belajar sesuai dengan tingkat pemahaman mereka. Diharapkan pembelajaran jarak jauh menggunakan video pembelajaran akan menanamkan konsep dasar, memahamkan konsep, mengatasi kejenuhan, dan meningkakan keterampilan serta menambah semangat belajar.

Berdasarkan uraian diatas maka rumusan masalah dalam best practice ini adalah Bagaimanakah pelaksanaan pemanfaatan video pembelajaran muatan pelajaran IPS dalam pembelajaran jarak jauh dapat meningkatkan motivasi dan hasil belajar siswa?

\section{METODE PENELITIAN}

Penelitian ini dilaksanakan di SD Negeri Wonosari I kelas VI C semester II tahun pelajaran 2020/2021 pada bulan Januari - Maret 2021. Metode penelitian ini adalah deskriptif kualitatatif berdasarkan fakta dan keadaan selama guru melaksanakan pembelajaran jarak jauh. Pada penelitian ini, data-data dikumpulkan melalui observasi, assessment, teknik dokumentasi terhadap datadata yang berkaitan dengan permasalahan motivasi dan hasil belajar siswa selama pembelajaran jarak jauh. Data-data yang dianalisis adalah keadaan awal, pelaksanaan pembelajaran dengan video pembelajaran, hambatan dan strategi pemecahan masalah, dampak serta tindak lanjutnya.

\section{HASIL DAN PEMBAHASAN}

Dalam pelaksanaan pembelajaran jarak jauh satuan pendidikan juga harus memperhatikan beberapa prinsip. Dalam (Permendikbud No. 24 Tahun 2016 Tentang Kompetensi Inti Dan Kompetensi Dasar Pelajaran Pada Kurikulum 2013 Pada Pendidikan Dasar Dan Pendidikan Menengah, 2016) terdapat 7 prinsip pembelajaran jarak jauh yang harus diperhatikan. Prinsip-prinsip tersebut yaitu pertama bahwa keselamatan dan kesehatan menjadi pertimbangan utama dalam penyelengaraan pembelajaran jarak jauh. Prinsip yang kedua adalah bahwa pelaksanaan pembelajaran jarak jauh dilaksanakan untuk memberikan pengalaman belajar yang bermakna tanpa membebani peserta didik. Selanjutnya prinsip yang 
ketiga adalah pembelajaran diutamakan pada penyampaian materi kecakapan hidup seperti pengetahuan tentang pandemi Covid-19. Prinsip keempat adalah pembelajaran disesuaikan dengan usia dan tingkatan pendidikan, latar belakang budaya, sifat, dan kondisi tertentu dari setiap peserta didik. Adapun prinsip kelima adalah kegiatan dan penugasan harus bervariasi menyesuaikan ketertarikan dan keadaan masing-masing peserta didik serta mempertimbangkan kemampuan dalam mengakses kesediaannya fasilitas pembelajaran. Prinsip keenam yang harus diperhatikan adalah adanya komunikasi interaktif. Guru diharapkan dapat memberikan umpan balik atau penilaian berguna secara kualitas tanpa harus memberikan penilaian skor/nilai secara terukur dengan angka saja. Prinsip terakhir adalah bahwa pelaksanaan pembelajaran jarak jauh harus mengutamakan komunikasi yang baik antara guru dan orang tua/wali.

Dengan adanya media pembelajaran maka siswa terbantu untuk memahami materi pembelajaran yang diberikan, walaupun mereka belajar di rumah masingmasing. Media pembelajaran juga dapat disesuaikan dengan karakteristik peserta didik dan kemampuan peserta didik dalam menggunakan media tersebut (Ahmadi et al., 2017). Selain itu, selama masa pandemi pendidik tidak dapat menemui peserta didik secara langsung, maka media video pembelajaran dianggap tepat untuk memudahkan pendidik menjelaskan materi-materi pembelajaran (Susilawati \& Yasir, 2021).

Media pembelajaran adalah sarana ataupun instrumen yang mendorong efektifitas dan efesiensi kegiatan pembelajaran, khususnya ketika peserta didik diharuskan belajar dari rumah selama masa pandemi virus corona (COVID 19) Media pembelajaran adalah segala sesuatu yang dapat digunakan untuk menyalurkan pesan dari pengirim ke penerima sehingga dapat merangsang pikiran, perasaan, perhatian, dan minat serta perhatian peserta didik sedemikian rupa sehingga proses belajar terjadi. (Sadiman, 2009). Penggunaan media pembelajaran yang adaptif dan berkualitas adalah salah satu cara untuk mewujudkan suasana belajar yang menyenangkan dan meningkatkan hasil belajar peserta didik. Video pembelajaran yang adaptif diharapkan mampu menarik perhatian peserta didik dalam memahami konsep. Untuk itu guru perlu mengadakan meningkatkan kreativitas dan inovasi dalam pembelajaran. 
Keadaan awal siswa yang kurang aktif pada pembelajaran jarak jauh, harus segera diatasi. Siswa yang merasa jenuh mengikuti pembelajaran jarak jauh harus dicarikan solusinya. Guru harus memikirkan pemenuhan hak siswa untuk memperoleh pendidikan terbaik, meskipun melalui pembelajaran jarak jauh. Guru harus mampu memberi warna yang berbeda pada kelas maya yang sudah dibuatnya. Guru tertantang untuk memanfaatkan teknologi sehingga menciptakan pembelajaran yang efektif sehingga mampu mengembalikan konsentrasi belajar siswa.

Strategi yang digunakan untuk meningkatkan motivasi dan hasil belajar siswa adalah pembelajaran kelas maya di Google Classroom. Pelaksanaan kegiatan pembelajaran dilakukan menggunakan Google Classroom. Google adalah perusahaan multinasional Amerika Serikat yang bergerak di bidang layanan jasa dan produk internet. Di bidang pendidikan Google meluncurkan produk Google Classroom yang bertujuan mengembangkan kegiatan pembelajaran tanpa kertas yang meliputi penyederhanaan pembuatan, pendistribusian dan pengumpulan tugas (Rosidah, 2020).

Strategi yang diterapkan guru yaitu: (1) Guru menyiapkan Rencana Pelaksanaan Pembelajaran (RPP); (2) Guru menyiapkan bahan pembelajaran (dalam hal ini video pembelajaran) dan penugasan kemudian mengunggah di Google Classroom; (3). Siswa mempelajari materi pembelajaran dan mengerjakan serta mengunggah tugas yang diberikan guru dengan media Google Classroom menggunakan handphone ataupun laptop; (4) Guru melakukan monitoring pelaksanaan proses pembelajaran jarak jauh .(5) Guru memberikan umpan balik atas pembelajaran jarak jauh dan tugas yang telah dikerjakan serta diunggah siswa.

Guru memulai kegiatan pembelajaran dengan perencanaan meliputi penyiapan Rencana Pelaksanaan Pembelajaran, lembar observasi, mempersiapkan lembar kerja siswa, dan video pembelajaran yang akan digunakan dalam pembelajaran jarak jauh. Desain Rencana Pelaksanaan Pembelajaran diuraikan pada tabel 1 dan 2 berikut!

Tabel 1. Desain RPP Pertemuan Pertama

Kegiatan Pendahuluan (10 menit)

Guru menyapa siswa melalui grup whatshap siswa kelas VI C dan google 
classroom, mengucap salam, memimpin doa, dan presensi kehadiran siswa menggunakan aplikasi zoho forms.

Guru memberikan informasi kepada siswa tujuan yang akan dicapai dari proses pembelajaran jarak jauh ini dengan mengaitkan materi sebelumnya dan pengalaman yang dimiliki siswa

Guru memberikan informasi kepada siswa materi yang akan dipelajari, kompetensi yang akan dicapai metode pembelajaran yang akan ditempuh

$$
\text { Kegiatan inti (50 menit) }
$$

Guru mengirimkan video pembelajaran melalui What's App grup dan google classroom.

Siswa menyimak video tersebut secara seksama

Guru memberikan informasi kesempatan siswa bertanya melalui what's app grup terkait dengan materi dalam video pembelajaran

Kegiatan penututup( 10 menit)

Siswa membuat rangkuman/ simpulan pelajaran tentang point-point penting yang muncul dalam kegiatan pembelajaran.

Tabel 2. Desain RPP Pertemuan Kedua

\begin{tabular}{l} 
Kegiatan Pendahuluan (10 menit) \\
\hline Guru menyapa siswa melalui grup whatshap siswa kelas VI C dan google \\
classroom, mengucap salam, memimpin doa, dan presensi kehadiran siswa \\
menggunakan aplikasi zoho forms. \\
Guru memberikan informasi kepada siswa tujuan yang akan dicapai dari \\
proses pembelajaran jarak jauh ini dengan mengaitkan materi sebelumnya \\
dan pengalaman yang dimiliki siswa \\
Guru memberikan informasi kepada siswa materi yang akan dipelajari, \\
kompetensi yang akan dicapai metode pembelajaran yang akan ditempuh \\
Kegiatan inti (50 menit) \\
Siswa diarahkan untuk memutar kembali video pembelajaran yang ada \\
What's App grup dan google classroom. \\
Siswa menyimak video tersebut secara seksama \\
\hline Guru memberikan informasi kesempatan siswa bertanya melalui what's \\
app grup terkait dengan materi dalam video pembelajaran, dan link google \\
meet yang bisa diikuti oleh seluruh siswa \\
\hline Guru mengirimkan penilaian berupa google form di google classroom \\
\hline Siswa diharapkan mengerjakan soal penilaian dengan mandiri dan jujur \\
\hline Kegiatan penututup( 10 menit) \\
\hline Siswa mengirim hasil kerjanya sebelum batas waktu yang diberikan. Guru \\
memeriksa hasil kerja siswa, menilai, dan memberikan komentar terhadap \\
hasil kerja siswa.
\end{tabular}

Pelaksanaan pembelajaran dilakukan guru dengan mengirimkan video 
pembelajaran . Video pembelajaran adalah salah satu cara mengatasi masalah tersebut. Video pembelajaran yang dibuat guru dapat mewakili kehadiran guru di kelas. Dengan mendengarkan suara guru diharapkan siswa akan lebih jelas memahami materi. Video pembelajaran dapat dilihat secara berulang-ulang, video juga mendorong dan meningkatkan motivasi siswa untuk melihatnya (Arsyad, 2009). Bagi siswa yang memiliki kemampuan belajar lebih cepat dapat menyingkat atau memperlambat waktu pemutarannya. Begitu juga untuk siswa yang belum memahami materi dapat mengulang kembali bagian-bagian tertentu yang diperlukan.

Dalam kegiatan pembelajaran komunikasi sangat diperlukan. Dalam situasi tertentu komunikasi menggunakan media merupakan proses penyampaian pikiran atau perasaan oleh seseorang kepada orang lain dengan menggunakan lambang-lambang yang bermakna bagi kedua belah pihak. Guru memfasilitasi google meet agar komunikasi pembelajaran dua arah. Komunikasi dapat mengubah sikap atau tingkah laku seseorang atau sejumlah orang. Dari komunikasi tersebut diharapkan menghasilkan efek tertentu (Effendy, 1993).

Siswa menyimak video tersebut secara seksama. Kegiatan pembelajaran jarak jauh dengan media video pembelajaran merupakan salah satu metode yang dapat diterapkan untuk memberikan pemahaman lebih mudah kepada peserta didik. Artinya peserta didik lebih mudah memahami materi karena kehadiran guru melalui video pembelajaran sehingga tidak cepat merasa bosan dan lebih mudah memahami materi. (Rusman, 2012) mengungkapkan beberapa kelebihan yang dimiliki media video yaitu: video dapat memberikan pesan yang dapat diterima lebih merata oleh siswa, video sangat bagus untuk menerangkan suatu proses, mengatasi keterbatasan ruang dan waktu, lebih realistis dan dapat diulang atau dihentikan sesuai kebutuhan, serta memberikan kesan yang mendalam, yang dapat mempengaruhi sikap siswa.

Hasil belajar mengalami peningkatan..Hasil penelitian ini sesuai dengan penelitian yang dilakukan oleh (Suryansah \& Suwarjo, 2016) yang menyatakan video menjadi salah satu sumber penting dalam memberikan informasi atau pengetahuan yang belum dipahami oleh siswa. Video mampu memberikan informasi yang dapat diamati secara langsung oleh siswa. Hasil pengamatan siswa 
akan menambah pengetahuannya dan meningkatkan hasil belajar kognitif siswa.Hasil sebaran nilai perolehan siswa dapat dilihat pada tabel berikut.

Tabel 3. Hasil Penilaian Muatan IPS

\begin{tabular}{ccc}
\hline Nilai & Jumlah Siswa & Kriteria \\
\hline 100 & 1 & Tuntas \\
\hline 95 & 3 & Tuntas \\
\hline 90 & 8 & Tuntas \\
\hline 85 & 12 & Tuntas \\
\hline 75 & 2 & Tuntas \\
\hline$<75$ & 2 & Belum Tuntas
\end{tabular}

Dari tabel 3 di atas, dapat dijelaskan bahwa 26 dari 28 siswa mencapai Kriteria Ketuntasan Minimal atau sebesar 92,86 \% . Rata-rata nilai yang diperoleh siswa 85,18 . Setelah selesai pembelajaran dan evaluasi guru memberikan angket tertutup berupa google form. Angket tersebut bertujuan untuk mengetahui bagaimana pendapat siswa terhadap pembelajaran menggunakan video pembelajaran. Hasilnya lebih dari $80 \%$ dan siswa merasa senang dan tertarik mengikuti pembelajaran. Hal tersebut ditunjukkan pula oleh meningkatnya ketepatan kehadiran siswa di kelas maya dan pengumpulan tugas tepat waktu.Pembelajaran jarak jauh dengan memanfaatkan video pembelajaran mampu meningkatkan motivasi belajar siswa. Motivasi belajar sendiri merupakan dorongan yang berasal dari diri peserta didik untuk mencapai tujuannya yaitu belajar (Emda, 2011). Motivasi belajar bukan hanya merupakan pendorong untuk tercapainya hasil yang memuaskan, namun juga terkandung usaha dalam mencapai tujuan dari belajar (Puspitasari, 2012). Motivasi belajar sangat berperan besar dalam keberhasilan peserta didik dalam kegiatan pembelajaran. Pemberian motivasi yang tepat akan membuat hasil belajar siswa semakin baik.

Pembelajaran jarak jauh dengan media video pembelajaran dapat terus diterapkan karena mampu meningkatkan hasil belajar. Cara pembuatan video pembelajaran juga cukup mudah dan murah. Video pembelajaran mampu menghadirkan guru di kelas maya. Bagi siswa yang masih mengalami kesulitan materi, pemutaran video pembelajaran dapat diputar berulang-ulang. Bagi siswa yang memiliki kelebihan kecepatan dalam belajar, pemutaran video dapat diatur bagian yang masih diperlukan. Dengan video pembelajaran, siswa pun menjadi 
lebih aktif dalam pembelajaran. Guru senantiasi kreatif dalam menyajikan materi pembelajaran agar motivasi dan hasil belajar terus meningkat.

Kendala yang dihadapi oleh guru saat pelaksanaan pembelajaran dengan menggunakan media video pembelajaran adalah sinyal seluler yang bermasalah. Kuota habis juga menjadi permasalahan tersendiri, karena tidak sedikit orang tua peserta didik yang tidak mampu membeli pulsa atau kuota internet. Gawai lelet juga menjadi hambatan selain bebarapa hambatan lainnya yang terjadi saat pelaksanaan pembelajaran dengan menggunakan media video pembelajaran. Namun hal tersebut dapat teratasi dengan adanya bantuan kuota internet dari pemerintah, sehingga pemanfaatan video pembelajaran tetap dapat dipilih sebagai alternatif media pembelajaran jarak jauh.

\section{SIMPULAN}

Sebagai simpulan dari artikel ini adalah pemanfaatan video pembelajaran muatan pelajaran IPS melalui pembelajaran jarak jauh dapat meningkatkan motivasi dan hasil belajar siswa kelas VI C SD N Wonosari I tahun Pelajaran 2020/2021. Kendala yang ada dapat diatasi sehingga pemanfaatan video pembelajaran dapat dikembangkan untuk muatan pelajaran lainnya

\section{DAFTAR PUSTAKA}

Ahmadi, F., Witanto, Y., \& Ratnaningrum, I. (2017). Pengembangan Media Edukasi "Multimedia Indonesian Culture" (Mic) Sebagai Penguatan Pendidikan Karakter Siswa Sekolah Dasar. Jurnal Penelitian Pendidikan, 34(2), 127-136. https://doi.org/10.15294/jpp.v34i2.12368

Arsyad, A. (2009). Media Pembelajaran. Raja Grafindo Persada.

Effendy, O. U. (1993). Ilmu, Teori, dan Filsafat Komunikasi. Citra Aditya Bakti.

Emda, A. (2011). Pemanfaatan Media Pembelajaran Biologi di Sekolah. Ilmiah DIDAKTIKA, 12(1), 149-162.

Permendikbud No. 24 Tahun 2016 Tentang Kompetensi Inti dan Kompetensi Dasar Pelajaran Pada Kurikulum 2013 Pada Pendidikan Dasar dan Pendidikan Menengah, (2016).

Puspitasari, D. B. (2012). Hubungan Antara Persepsi Terhadap Iklim Kelas Dengan Motivasi Belajar Siswa SMP Negeri 1 Bancak. Jurnal Empathy, $1(1), 60-67$. 
Rosidah, A. (2020). Pemanfaatan Google Classroom Untuk Pembelajaran Online. PTP LPMP DKI Jakarta.

Rusman. (2012). Belajar dan Pembelajaran Berbasis Komputer. Alfabeta.

Sadiman, A. S. (2009). Media Pendidikan (14th ed.). Raja Grafindo Persada.

Suryansah, T., \& Suwarjo, S. (2016). Pengembangan Video Pembelajaran Untuk Meningkatkan Motivasi Dan Hasil Belajar Kognitif Siswa Kelas Iv Sd. Jurnal Prima Edukasia, 4(2), 209. https://doi.org/10.21831/jpe.v4i2.8393

Susilawati, \& Yasir, M. (2021). Transformasi Media Pembelajaran pada Masa Pandemi. Jurnal Pengabdian Pada Masyarakat, 1, 263-272. 